\title{
RNA-Binding Protein 10
}

National Cancer Institute

\section{Source}

National Cancer Institute. RNA-Binding Protein 10. NCI Thesaurus. Code C115386.

RNA-binding protein 10 (930 aa, $104 \mathrm{kDa}$ ) is encoded by the human RBM10 gene. This protein is involved in RNA metabolism. 